\title{
ODP activities on the South-East Greenland margin: Leg 152 drilling and continued site surveying
}

\author{
H. C. Larsen, A. Saunders, L. M. Larsen, H. Lykke-Andersen, \\ ODP Leg 152 shipboard party, C. Marcussen and L. Clausen
}

Two main types of passive margins known as volcanic and non-volcanic rifted margins, based on the extent of volcanic activity associated with their formation, are widely recognised. Volcanic rifted margins have now been identified along the edges of many continents (Coffin \& Eldholm, 1992) and cannot any longer be considered as rare exceptions to 'normal' (non-volcanic) continental break-up.

In previous years the Geological Survey of Greenland (GGU) has been involved in the planning and pre-drilling site surveying for scientific drilling at volcanic rifted margins within the Ocean Drilling Program (ODP; see Larsen, 1993 for review). In 1993 these activities continued with site surveying for future ODP drilling at the South-East Greenland margin in August-September, and Leg 152 of the Ocean Drilling Program completed the first of two planned drilling legs at this margin in September-November (Fig. 1).

While the primary objective of the margin study is the fundamental process of break-up, considerable important information on the subsequent sedimentation along the margin can be obtained through both the high-resolution seismic surveying and the drilling. A particularly interesting aspect is the late Neogene climatic change and the transition into the present, glaciated environment as recorded in the stratigraphic record.

\section{Leg 152}

The initial opening of the North-East Atlantic some $55 \mathrm{Ma}$ ago was accompanied by intense volcanic activity, now preserved on land as Tertiary flood basalt provinces in Greenland, northern Britain and the Faeroe Islands, and along the submerged margins of the North Atlantic as thick, seaward-dipping reflector sequences (SDRS) (Morton \& Parson, 1988). These are more voluminous than adjacent, on-land basaltic provinces, and provide important information, not only about the development of the rifted margin, but also about the thermal state of the mantle during rifting. It is widely held that in the North-East Atlantic, for example, the extensive magmatism was a direct result of continental break-up above a widespread, hot ancestral Iceland plume (White \& McKenzie, 1989).
Seaward-dipping reflector sequences have previously been studied by ocean drilling on the Rockall Plateau (DSDP Legs 48 and 81) and on the Vøring Plateau (DSDP Leg 38 and ODP Leg 104). Leg 152 was designed to extend studies into the detailed nature of the processes operating at volcanic rifted margins. Along much of the South-East Greenland margin, a $150 \mathrm{~km}$ wide belt of seaward-dipping lavas borders and laps onto the continental crust (Larsen, 1990). The lavas wedge out before reaching the Greenland coast (Fig. 2), but thick accumulations of basalt occur farther north in the Kangerlussuaq and Scoresby Sund regions (e.g. Larsen et al., 1989).

Drilling at six sites during Leg 152 across the SouthEast Greenland continental shelf and into the adjacent Irminger Basin has provided a wealth of information about the tectonic and volcanic development of this type of margin, including the first penetration through the volcanic cover into the underlying continental crust (Larsen et al., in press a). Additionally, the recovered sediments give a detailed chronology of oceanographic and climatological events in the North Atlantic, including the discovery that glaciation began in southern Greenland as long as $7 \mathrm{Ma}$ ago, far earlier than previously thought. Glaciation was preceded by the influx of North Atlantic deep water into the Irminger Basin (Larsen et al., in press b).

\section{Recovery of volcanic rocks}

The drill sites were selected to sample both the featheredge (Sites 914, 915, 916 and 917), and the central part (Site 918) of the seaward-dipping lavas, thus demonstrating differences in material erupted during the early stages of volcanism and during 'steady-state' SDRS growth (Fig. 2). Drilling was particularly successful in terms of recovery of volcanic rocks at two of the sites (917 and 918). At Site 917 a total of $780 \mathrm{~m}$ of basaltic, dacitic and picritic lavas and, through a faulted contact, underlying metasedimentary basement was penetrated at the feather-edge of the SDRS. The excellent recovery provides a detailed record of the early development of the SDRS, although the lowermost $300 \mathrm{~m}$ of the SDRS remain unsampled. At Site 918, some $70 \mathrm{~km}$ to the south-east of Site $917,120 \mathrm{~m}$ of basalts from the central part of the SDRS were drilled, in addition to 


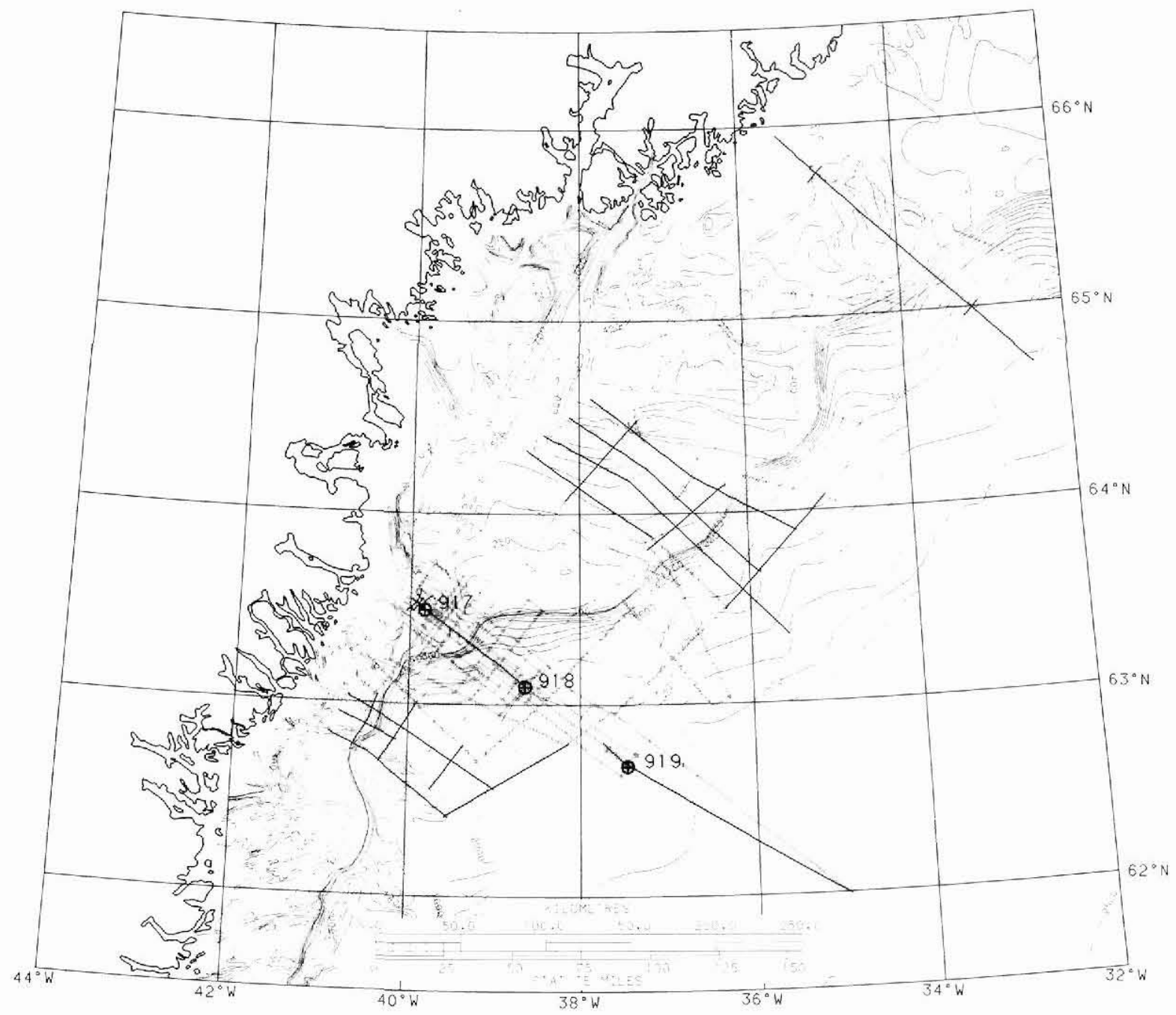

Fig. I. Map of the South-East Greenland margin and the adjacent deep Irminger Basin, showing regional bathymetry and the location of Leg 152 drill Sites 914-919. Seismic lines acquired in 1993 and 1994 (bold lines) are also shown. Note how the narrow troughs on the inner shelf are related to the major ljords and continue onto the outer shelf as broad. transverse troughs. Marked lobes at the shelf edge are present in front of the troughs. High-grade basement is exposed within the fjord zone and below the inner shelf. The outer shelf is floored by Tertiary and Quaternary sediments overlying carly Tertiary basaltic lavas.

\section{$1170 \mathrm{~m}$ of lower Eocene to Recent sediments.}

The volcanic sequence recovered from well $917 \mathrm{~A}$ has at least 92 individual units which have been grouped into three series. The upper series comprises olivine basalts and picrites (with up to $25 \% \mathrm{MgO}$ ); the middle series contains evolved tholeiitic basalts and dacites; and the lower series comprises olivine tholeiites and occasional picritic basalts (Fig. 3). Both pahoehoe and aa flow structures are seen; the pahoehoe flows predominate in the upper series. Reddened flow tops, occasional inter-flow sediments and a total lack of pillow structures indicate that the flows were erupted subaerially. Individual units range from $0.5 \mathrm{~m}$ to $55 \mathrm{~m}$ in thickness, indicating voluminous, flood-like eruptions. The entire lava pile now dips about $20^{\circ}$ towards the south-east, and sits atop steeply dipping, low-grade metamorphic siltstones and mudstones, which may correlate with parts of the Paleocene formations outcropping along the coast north of Site 917 (Nielsen et al., 1981). If the metasediments really are of Paleocene age, then they testify to strong tectonism and basement rotation shortly before the emplacement of the lavas.

Whole rock analyses show that the upper series lavas are primitive basalts and picrites with high contents of $\mathrm{MgO}$ and $\mathrm{Ni}$, even in the phenocryst-free samples (Fig. 3). Preliminary data reveal trace element abundances and ratios consistent with derivation from a depleted midocean ridge basalt (MORB) source. The lower and middle series lavas, however, have substantially higher $\mathrm{Ba} / \mathrm{Zr}$ and 


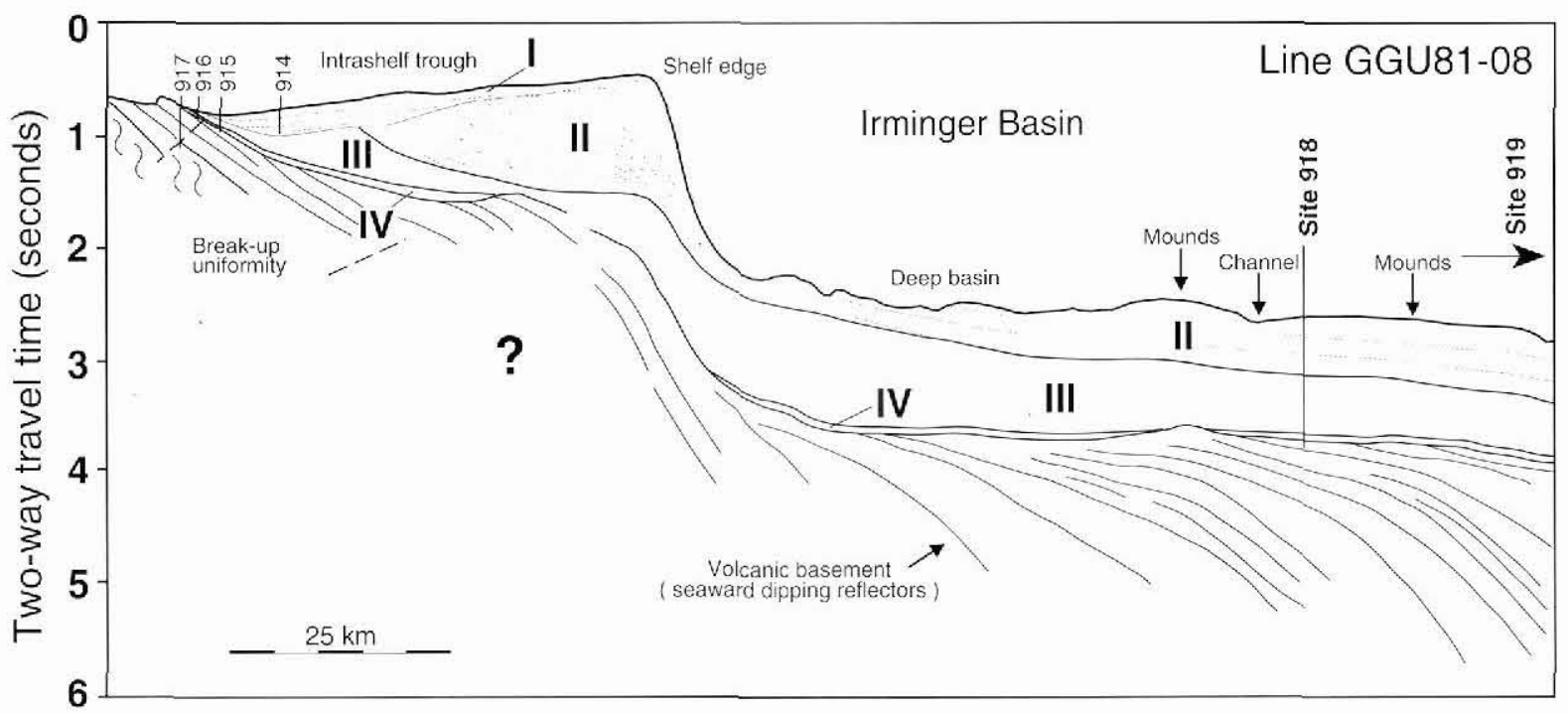

Fig. 2. Interpreted seismic section across the South-East Greenland margin. Seismic units I - IV are shown. Large scale section showing the shelf edge, with its thick glaciomarine fan. Sites 914 through 918 are indicated; Site 919 is located to the south-east in the lrminger Basin. For full explanation see text.

higher abundances of $\mathrm{K}$ and $\mathrm{Ba}$ suggesting that the earliest SDRS magmas reacted with continental lithosphere.

Overlying the lavas at Sites 915,916 and 917 are thin units of volcaniclastic breccia and conglomerate, overlain in turn by middle and upper Eocene volcaniclastic sandstone and siltstone. The facies assemblages indicate a range of lagoonal, fluvial or shallow marine environments at this time. More open marine conditions, resulting from subsidence, were established during the early Oligocene.

At Site 918, on the main, steady-state development of the SDRS, the volcanic basement sequence again comprises tholeiitic basalt flows; some 18 individual flow units were identified. The top flows are separated by layers of basaltic breccia. The eruption environment appears to have been subaerial possibly with occasional incursions into shallow water. Lower Eocene sediments, deposited in a shallow marine environment, were deposited shortly after eruption of the lavas (Fig. 4). The basalts at Site 918 show a limited range of $\mathrm{MgO}$ values close to normal MORB levels (Fig. 3).

The basalts from Sites 915, 917 and 918 show reverse magnetic polarity. Regional aeromagnetic data, and the presence of lower Eocene nannofossils in the overlying sediments at Site 918 suggest that the lavas were erupted during chron $\mathrm{C} 24 \mathrm{r}$. This would indicate that the entire $150 \mathrm{~km}$ width of the SDRS was emplaced during the same magnetic chron, a period of no more than $2.9 \mathrm{Ma}$. This implies a spreading rate of $5 \mathrm{~cm} / \mathrm{y}$, which is substantially faster than subsequent spreading rates along the Reykjanes Ridge. Extrusion rates were even higher than those on Iceland (e.g. Larsen \& Jakobsdóttir, 1988).
Despite convincing evidence found during Leg 152 for a strong thermal anomaly, there is little or no evidence in the lavas for compositional input other than from depleted, normal MORB mantle and, in some of the lavas, contamination from the continental lithosphere. Compositionally-depleted MORBs were also recovered from the seaward-dipping reflector sequences of the south-western Rockall Plateau, which is approximately conjugate to the South-East Greenland transect (Joron et al., 1984). Clear evidence of a genetic relationship between deep-seated mantle plumes and volcanic rifted margins is therefore still lacking. It would appear, however, that at these distances from the ancestral plume axis which was located beneath central Greenland in chron 24 times, some $500-600 \mathrm{~km}$ north of the South-East Greenland margin (White \& McKenzic, 1989), the input was predominantly thermal and not compositional. Closer to the plume axis, for example around central East Greenland, basalts with clear Icelandic (plume) characteristics are found (Larsen et al., 1989).

\section{Glacial deposits and Greenland glaciation}

The Greenland ice sheet is the only continental ice sheet in the northern hemisphere which has survived the present interglacial period. The fragmentary land record suggests that the glaciation of Greenland did not start before about 2 Ma ago (Funder, 1989), and was associated with or following the major increase in North Atlantic ice volumes about $2.5 \mathrm{Ma}$ ago (Jansen et al., 1988, 1990; Ruddiman \& Raymo. 1988). The Early Eocene to Holocene sediments recovered during Leg 152 , however, contain a relatively 

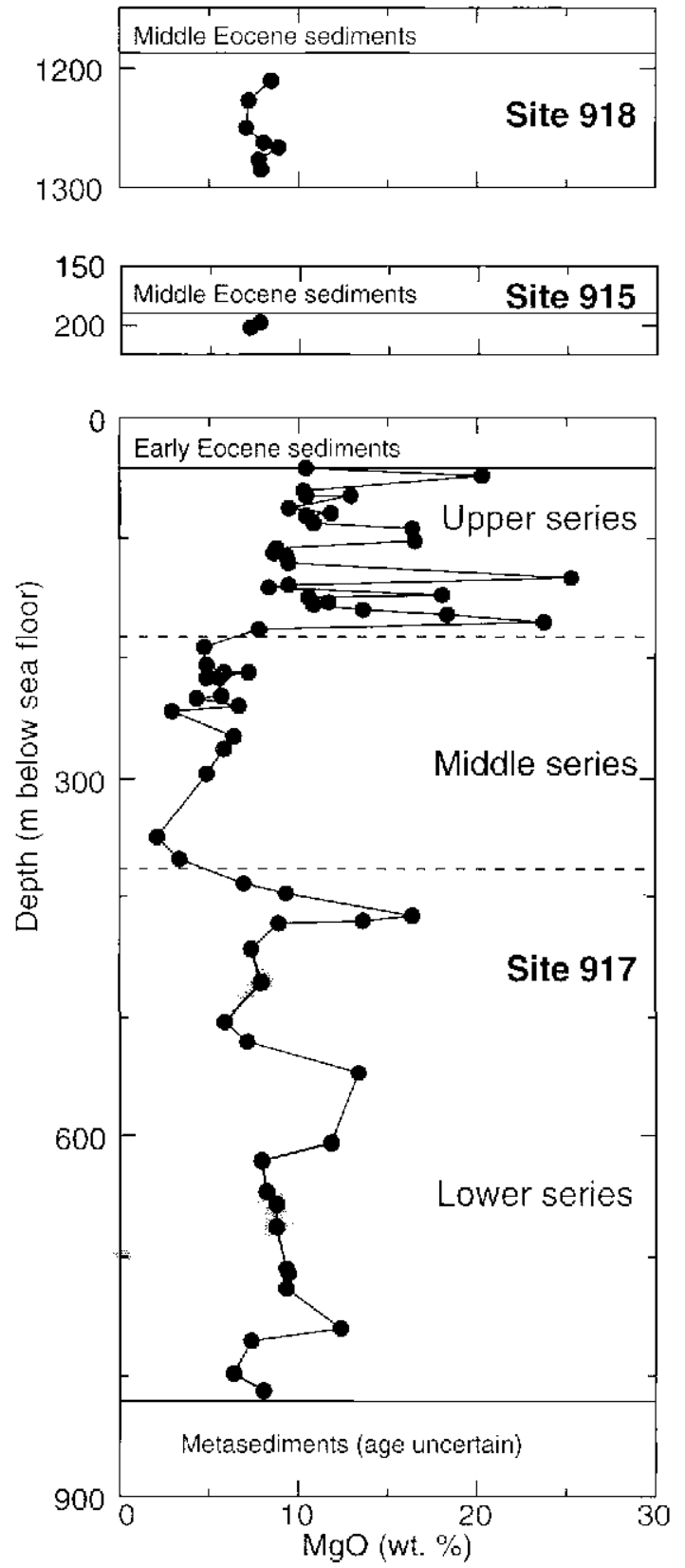

Fig. 3. Depth versus $\mathrm{MgO}$ content for the lavas recovered from Sites 915,917 and 918 on the South-East Greenland margin. Note the strong fluctuations in $\mathrm{MgO}$ content in the upper series lavas from Site 917. The middle series lavas have lower MgO contents, reflecting their more evolved compositions.

complete record of multiple glaciations which affected southern Greenland as far back as $7 \mathrm{Ma}$ ago (Fig. 4).

The upper $543 \mathrm{~m}$ of the sediments from Site 918 contain numerous ice-rafted dropstones and beds of poorly sorted clay, silt, sand and angular gravel of glaciomarine origin. The glacial deposits are found in several levels reflecting episodes of intense glaciation. The clast assemblages comprise high grade metamorphic and non-metamorphic basaltic rocks, which together uniquely define the source area as South-East Greenland. The oldest sediment with unequivocal ice-rafted material is of Late Miocene age, deposited approximately 7 Ma ago. This predates previous estimates of the timing of the onset of Greenland glaciation by 4 to $5 \mathrm{Ma}$. The glacial record at Site 918 also shows the presence during the Pliocene of intermittent periods of little or no glaciation.

Thick layers of late Terliary to Quaternary glacial deposits occur at all of the shelf sites (Fig. 2, and below), and confirm that thick. grounded shelf ice existed at least during one, and perhaps several, of the later glacial maxima; this testifies to the extreme climatic variability in this region during late Cenozoic time.

\section{Site survey activities}

A high resolution seismic survey was carried out in the shelf area and adjacent deep sea area offshore South-East Greenland in September 1993. as a supplement to a 1992 seismic survey in the same region (Fig. 1; Larsen, 1993). These seismic activities support ODP's NARM project (North Atlantic Rifted Margins), and is a joint project between GGU, the Geological Survey of Denmark, and the Universities of Aarlus and Copenhagen, with support from the Danish Natural Science Research Council. Approximately $1740 \mathrm{~km}$ of seismic data were acquired in 1993, which including the 1992 data adds up to a total of $4500 \mathrm{~km}$.

\section{3 survey operations}

The 1993 seismic grid was designed to cover a transition from transverse shelf trough and trough mouth fan to deep basin in two areas (Fig. 1). These were covered by $c$. $400 \mathrm{~km}$ and $c .700 \mathrm{~km}$ of seismic lines, respectively, which tje in with the 1992 scismic grid. In addition the 1993 seismic dala provide site specific data for proposed future ODP drill sites at the South-East Greenland margin.

The seismic survey was executed from the Dutch research vessel R/V Pelagia charlered from NIOZ (Netherlands Institute of Sea Research). The recording equipment consisted of a 24 group. $144 \mathrm{~m}$ long streamer and a 24 channel Geometrics digital recording system. A point source array of four sleeve guns each of 160 cubic inches was fired every $12.5 \mathrm{~m}$ on the shelf and every $18.7 \mathrm{~m}$ in deep water, and recorded to between 2 and 3 seconds (TWT) below sea floor. The processed seismic data are of high resolution and show penetration of up to 0.5 seconds into the basaltic basement, except for shallow shelf areas where prominent sea bed multiples very strongly overprint and largely hinder 
identification of primary features in the lower part of the sedimentary succession and the basalts beneath. The 1993 seismic data will be processed to final stack during the spring of 1994.

Single channel seismic data, magnetic data and echo sounding data were also recorded during the survey.

\section{Preliminary interpretation}

Preliminary studies suggest that the sedimentary succession above the volcanic basement in the key shelf area can be divided into at least four major seismic stratigraphic units, of which the three lower units can more or less be followed nto the deep sea (Fig. 2).

The two lowermost units are separated by an onlap surface (angular unconformity) in the shelf area. Unit IV, of Eocene age according to the shipboard midrofossil data from Leg 152 , is characterised by a seawards dipping divergent seismic pattern, whereas the overlying unit III, of Early Oligocene age, is characterised by seawards dipping and discontinuous seismic reflectors. These two units are bounded upwards by an irregular unconformity which, on the central part of the shelf, clearly shows truncation of the units IV and III. On the main outer part of the shelf the unconformity separates units IV and III from an overlying prograding unit II. The unconformity can be followed below the prograding unit to the shelf slope and further seawards into the deep water area.

The shelf part of unit II, which according to Leg 152 drilling is likely to be of late Miocene to Pleistocene age, is characterised by a complex sigmoid oblique seismic pattern (Fig. 2). It is bounded upwards and cut out landwards by a major, landward dipping, irregular unconformity separating it from the overlying unit I. This unconformity in general appears to represent erosion on the landward part of the shelf and/or depositional bypass on the central part, but it possibly represents a strongly condensed interval in places, in particular on the outer shelf. The chronostratigraphic significance of the unconformity between units II and I therefore varies from place to place, and clearly, the younger parts of unit II are coeval with parts of unit I.

Towards the shelf break unit II shows an increasing aggradation, where it causes seawards-convex bathymetry. The prograding unit II is most likely of glaciomarine origin. Numerous lower order sequences can be identified within unit II, which most likely reflect progradation and aggradation of the shelf during successive advances of a grounded ice sheet (Boulton, 1990), fig. 30). Unit II has a lobate geometry in the key study area. Southwards it merges with other lobe areas. Intermittent shallower banks formed where the lobate prograding units amalgamate, and hence part of the 'glacial' morphology on the shelf

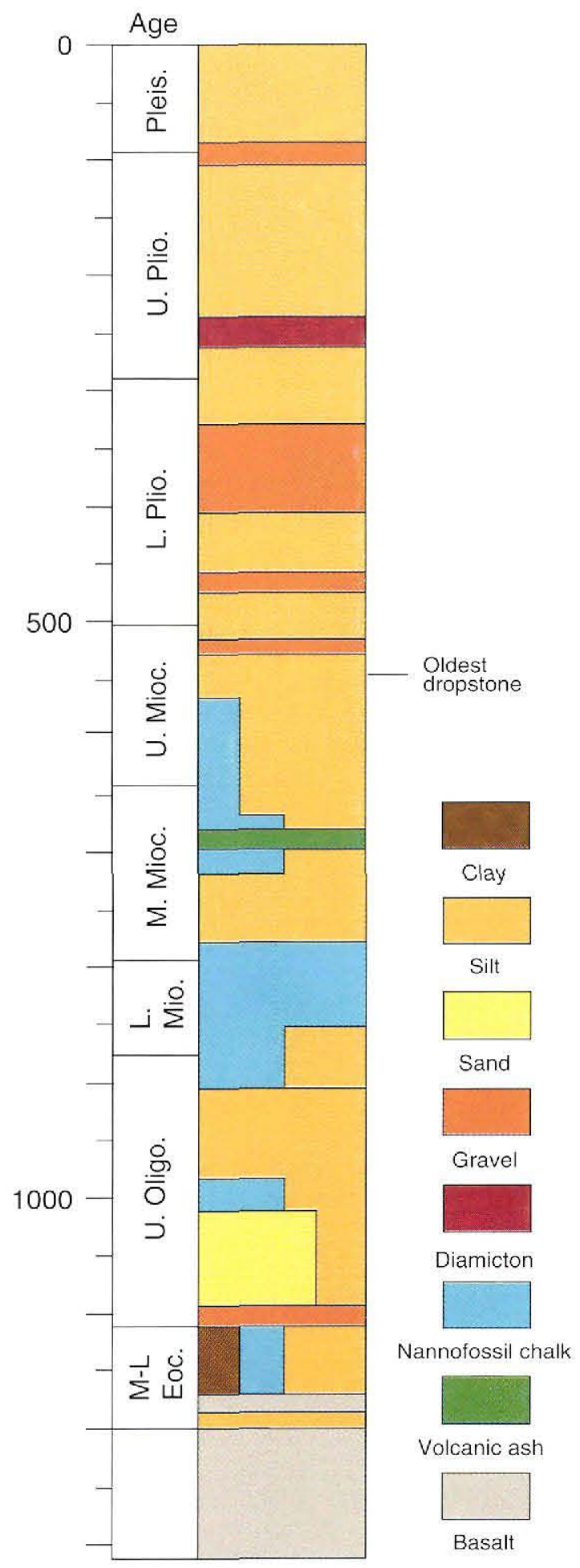

Fig. 4. Stratigraphic column for Site 918, from the western Irminger Basin, South-East Greenland, illustrating the main geological features discovered during Leg 152. The total depth of penetration of sediment and basalt was $1310 \mathrm{~m}$ below mean sea level. 
with deep troughs and banks are constructional rather than erosional.

Unit II is thickest at the shelf break and thin at the base of the shelf slope, but it can be followed farther out into the Irminger Basin where it comprises an approximately $500 \mathrm{~m}$ thick succession, characterised by seawards dipping, strong amplitude and relatively continuous reflectors of high frequency. The upper part of the succession is quite complex and comprises 100-200 m high mounds containing numerous internal unconformities. The mounds seem to be constructional rather than representing erosional remnants. Mounds located along the lower part of the slope may represent slides or debris flows. These mounds are transitional into more distal mounds separated by $\mathrm{N}-\mathrm{S}$ trending channels. The latter are taken to represent a channel-levee complex of a deep sea fan fed by turbidity currents originating at the shelf break to the north.

Unit I is of more local extent, and is characterised by internal subhorizontal to landward dipping internal reflectors and unconformities. This succession blankets the intrashelf trough deposits and in places extends as a thin veneer to the shelf break, where it amalgamates with the prograding unit II. High-shear strength strata within unit I were penetrated during Leg 152 drilling and can be interpreted as a basal till deposited below a surging shelf ice (Larsen et al., in press b).

\section{Future objectives}

The 1993 high resolution seismic survey was the second of two planned survey seasons. The approximately $4500 \mathrm{~km}$ of new high resolution data and older seismic data in the region (see Larsen, 1990 for review) will be used together with drilling data from Leg 152 in a seismic stratigraphic study of the region.

In terms of deep drilling Leg 152 was the first of a series of drilling legs that have been proposed for the South-East Greenland margin. Future drilling, for which the necessary site survey data now exists, will hopefully investigate the oldest part of the dipping reflectors and the underlying rift structure, inland of the Leg 152 transect. Sampling of 'normal' oceanic crust at Site 919 would complete the transect at $63^{\circ} \mathrm{N}$. A second objective is a similar, but more condensed transect at about $66^{\circ} \mathrm{N}$, closer to the ancestral Iceland plume. Here, the SDRS are expected to show clearly a compositional input from the plume, from which thermal and compositional models of the plume system can be tightly constrained.

Complementary land-based geological studies and shipbased geophysical studies of the deep margin structure are being planned by the recently-formed Danish Lithosphere Centre (Ghisler, this report), in collaboration with a number of international partners. Deep seismic surveys are planned for 1994 and 1995 in order to determine the extent of magmatic underplating associated with the emplacement of the dipping reflectors and the crustal structure prior to break-up (cf. White et al., 1987). Onshore work will complete the sampling of the early plume activity. Plans are underway for a $6 \mathrm{~km}$ deep borehole on the coast at $66^{\circ} \mathrm{N}$, targeting the deep margin structure in an area where highlevel gabbros are present. These may represent a more extensive occurrence of gabbros at depth which may have formed a detachment layer for upper crustal extension during break-up.

Acknowledgements. Danish participation in the Ocean Drilling Program and the seismic site survey is funded by the Danish Natural Research Council.

\section{References}

Boulton, G. S. 1990: Sedimentary and sea level changes during glacial cycles and their control on glacimarine facies architecture. In Dowdeswell, J. A. \& Scourse, J. D. (ed.) Glacimarine environment: processes and sediments. Spec. Publ. geol. Soc. Lond. 53, 15-52.

Coffin, M. F. \& Eldholm, O. 1992: Volcanism and continental break-up: a global compilation of large igneous provinces. In Storey, B. C., Alabaster, T. \& Pankhurst, R. J. (ed.) Magmatism and the causes of continental break-up. Spec. Publ. geol. Soc. Lond. 68, 17-30.

Jansen, E., Bleil, U., Henrich, R., Kringstad, L. \& Slettenmark, B. 1988: Paleoenvironmental changes in the Norwegian Sea and the northeast Atlantic during the last $2.8 \mathrm{Ma}$ : DSDP/ODP Sites 610, 642, 643, 644. Paleooceanography 3, 563-581.

Jansen, E., Sjøholm, J., Bleil, U. \& Eriksen, J. A. 1990: Neogene and Pleistocene glaciations in the Northern Hemisphere and late Miocene - Pliocene ice volume fluctuations: evidence from the Norwegian Sea. In Bleil, U. \& Thiede, J. (ed.) Geological history of the polar oceans: Arctic versus the Antarctic, 677705. Dordrecht: Kluwer Academic Publishers.

Joron, J.-L., Bougault, H., Maury, R. C., Bohn, M. \& Desprairies, A. 1984: Strongly depleted tholeiites from the Rockall Plateau margin, North Atlantic: geochemistry and mineralogy. In Roberts, D. G. et al. (ed.) Initial reports of the Deep Sea Drilling Project 81, 783-794. Washington: U.S. Govt Printing Office.

Larsen, H. C. 1990: The East Greenland Shelf. In Grantz, A., Johnson, L. \& Sweeney, J. F. (ed.) The Arctic Ocean region. The geology of North America L, 185-210. Boulder, CO: Geol. Soc. Amer.

Larsen, H. C. 1993: Ocean Drilling Program (ODP) off SouthEast Greenland: formation of a volcanic rifted margin. Rapp. Grønlands geol. Unders. 159, 69-73.

Larsen, H. C. \& Jakobsdóttir, S. J. 1988: Distribution, crustal properties and significance of seawards-dipping sub-basement reflectors off E. Greenland. In Morton, A. C. \& Parson, L. M. (ed.) Early Tertiary volcanism and opening of the NE Atlantic. Spec. Publ. geol. Soc. Lond. 39, 95-114.

Larsen, L. M., Watt, W. S. \& Watt, M. 1989: Geology and petrology of the Lower Tertiary plateau basalts of the Scoresby Sund region, East Greenland. Bull. Grønlands geol. Unders. 157, 164 pp. 
Larsen, H. C., Saunders, A., Clift, P. \& ODP Leg 152 scientific party, in press a: Fire and ice: the SE Greenland margin drilled by ODP Leg 152. Eos

Larsen, H. C., Saunders, A., Clift, P. \& ODP Leg 152 scientific party, in press $b$ : Seven million years of glaciation in Greenland. Science

Morton, A. C. \& Parson, L. M. (ed.) 1988: Early Tertiary volcanism and the opening of the NE Atlantic. Spec. Publ. geol. Soc. Lond. 39, 477 pp.

Nielsen, T. F. D., Soper, N. J., Brooks, C. K., Faller, A. M., Higgins, A. C. \& Matthews, D. W. 1981: The pre-basaltic sediments and the lower lavas at Kangerdlugssuaq, East Greenland. Their stratigraphy, lithology, paleomagnetism and petrology. Meddr Gronland, Geoscience 6, 25 pp.

Ruddiman, W. F. \& Raymo, M. E. 1988: Northern hemisphere climate regimes during the last $3 \mathrm{Ma}$; possible tectonic connections. Phil. Trans. R. Soc. Lond. B 318, 411-430.

White, R. S. \& McKenzie, D. 1989: Magmatism at rift zones: The generation of volcanic continental margins and flood basalts. J. geophys. Res. B94, 7685-7729.

\section{ODP Leg 152 Scientific Party}

H. C. Larsen, A. D. Saunders, P. D. Clift, J. Ali, J. Begét, H. Cambray, A. Demant, G. Fitton, M. S. Fram, K. Fukuma, J. Gieskes, M. A. Holmes, J. Hunt, C. Lacasse, L. M. Larsen, H. Lykke-Andersen, A. Meltser, M. L. Morrison, N. Nemoto, N. Okay, S. Saito, C. Sinton, S. Spezzaferri, R. Stax, T. L. Vallier, D. Vandamme, W. Wei, R. Werner.

H. C. L., Danish Lithosphere Centre, Øster Voldgade 10, DK-1350 Copenhagen, Denmark

L. M. L. \& C. M., Geological Survey of Greenland, Copenhagen A. D. S., Department of Geology, University of Leicester, University Road, Leicester LE1 7RH, UK

H. L.-A., Geological Institute, University of Aarhus, Finlandsgade 8, DK-8200 Århus, Denmark

L. C., Geological Institute, Øster Voldgade 10, DK-1350 Copenhagen, Denmark 